\title{
EFFECT OF CRUDE PROTEIN LEVELS AND FOLLICLE STIMULATION ON EGG PRODUCTION OF AGED HENS
}

\author{
V. A. TOGUN ${ }^{* 1,2}$; J. I. OKWUSIDI ${ }^{1}$; O. A. AMAO ${ }^{2}$; and S. U. ONYIAOHA ${ }^{3}$ \\ ${ }^{1}$ Department of Physiology, Faculty of Basic Medical Sciences; \\ ${ }^{2}$ Department of Animal Production and Health; Faculty of Agricultural Sciences \\ ${ }^{3}$ Commercial Farm, Ladoke Akintola University of Technology, P.M.B. 4000, \\ Ogbomoso, Nigeria.
}

\begin{abstract}
Summary: The effects of varying levels of crude protein and follicle stimulation were studied on the recovery and performance of one hundred post moulted, aged, Nera Black Hens. Moulting was induced at production capacity of $33.6 \%$. The birds were thereafter randomly assigned to four (4) groups (each of two replicates). Two groups received 16\% crude protein (CP) level diets and the other two groups, 32\%. One each of the two groups received follicle stimulation, induced by administration of Clomifene citrate $(1.5 \mathrm{mg} / \mathrm{kg}$ ) via cathetered $5 \mathrm{ml}$ syringe through the 10 week experimental period, with feed and water offered ad libitum. Egg production ceased on day 5 of forced moulting. Postmoult menarche and return to pre-moult status had occurred on days 4 and 8 respectively in all the groups. Post-moult hen-day peak production performance was $87.5 \%, 91.7 \%, 68.0 \%$ and $83.3 \%$ for birds assigned to $16 \% \mathrm{CP}$ diet without follicle stimulation (Group 1 - control), 16\% CP diet plus follicle stimulation (Group 2), 32\% CP diet without follicle stimulation (Group 3) and 32\% CP plus follicle stimulation (Group 4). Post-moult mean weekly production performance was $69.66 \%$; $67.26 \%$; $56.40 \%$ and $63.69 \%$ for groups 1,2,3 and 4 hens respectively. Follicle stimulation enhanced post-moult production performance especially the hen-day performance in birds on $16 \% \mathrm{CP}$ diet. Higher protein diet did not per se enhance peak production, post-moult menarche and return to pre-moult status.
\end{abstract}

Key Words: $\quad$ Moulting; Aged hens; Crude protein; Follicle Stimulation Hen-day, menarche.

\section{Introduction}

Moulting (resting) in birds is a physiological phenomenon as in most animals. It is characterized by shedding of feathers along with a suspension of egg production during this period of rest thus bringing about a condition that allows time for tissue regeneration. Moulting has been induced through various manipulations using drugs (Swanson and Bell, 1970), nutrition (Zvykas, 1977; Odunsi et al, 2002) and a combination of nutrition and photoperiod (Dubinskii et al, 1973; Oguike and Ezeoke, 2003). Various investigators have reported increases in egg production of birds induced to moult (Decuypere and Verheyen,1986 and Bar et al, 2001). A production of between $70-75 \%$ has been reported in force moulted birds (Swanson and Bell 1970). Moniterio et al (1971) reported no significant difference in egg production between force and naturally moulted birds. Available information have generally centered on younger birds with a first moulting experience (Odunsi et al, 2002; Oguike and Ezeoke, 2003). There is however a paucity of information on older birds with or without previous moulting experiences and the effects of varying crude protein intake and follicular stimulation on moulting dynamics.

This study was therefore undertaken to investigate the effects of varying levels of crude protein (CP) and follicle stimulation (FS) on post moulting (PM) recovery and performance in aged (756 days) Nera Black Hens (NBH).

\section{Materials and Methods}

One hundred, 108-week old NBH at 92 weeks in lay were used in the study. Production capacity of the fowls at the commencement of force moulting was $33.6 \%$. The birds were individually housed in standard battery cages. Moulting was induced by an adaptation of the method by Odunsi et al (2001). Briefly; the birds were deprived of feed and water for 3days, followed by feed withdrawal alone for the next 2days. Ground maize at $30 \mathrm{~g} / \mathrm{hen} /$ day was provided for the next 2days and water alone for another 3days. Finally ground maize plus $0.025 \mathrm{~g} / \mathrm{kg}$ layers 
premix was given for the next 2days and water alone for the final 3days of the moulting protocol.

At the end of 15days, the moulted birds were randomly assigned to Four (4) groups of varying $\mathrm{CP}$ levels in diets diets plus $(+)$ or without FS as follows:

Group 1 - 16\% (16\% CP without FS -Control)

Group $2-16 \%+(16 \%$ CP + FS )

Group $3-32 \% \quad$ (32\% CP without FS )

Group $4-32 \%+(32 \%$ CP + FS )

Each group of 50 birds was divided into two replicates of 25 birds each. Follicle stimulation was induced by the administration of Clomifene citrate (CC). Clomifene citrate induces fertility through stimulation of ovulation in human subjects by stimulating the production of pituitary gonadotropins. Five tablets of $\underline{\mathrm{CC}}$ (50mg each) were suspended in $25 \mathrm{ml}$ of table water. Each hen received a dose of $1.5 \mathrm{mg} / \mathrm{kg}$ body weight by gavage via catheter attached to $5 \mathrm{ml}$ syringe between 7.00 am. - 8.00 am daily for 10 weeks (70 days). Feed and water were given ad libitum. Egg production, as an index of folliculation, was recorded daily.

\section{Experimental Design and Statistical Analysis:}

The experimental design was Completely Randomized Factorial. Data collected were analyzed using general linear model of SPSS package. A $\mathrm{p}<0.05$ was considered significant.

\section{Results}

Egg production ceased on day 5 of FM. Post moult menarche was noticed in group 1 (control) on day 1; in groups 3 and 4 on day 3 and in group 2 on day 4 after FM. (Table 1). On the average, egg production returned to the pre-moult status of $33.6 \%$ on the $8^{\text {th }}$ after FM (Table 1).

The attainment time (day) of PM peak hen-day production performance is shown in Table 2. Group 2 hens peaked at $91.7 \%$ on day 49 after FM compared to groups 1,3 and 4 that peaked at $87.5 \%, 68.0 \%$, and $83.3 \%$ on days 34, 27 and 28 respectively.

Table 3 shows the average weekly egg production recovery performance of the aged hens. Groups 1, 3 and 4 peaked on week 4 at $69.66 \%, 56.40 \%$ and $63.69 \%$ compared to group 2 that peaked on week 7 at $67.26 \%$. The mean egg production performance during the 10 - week treatment period was $59.48 \%$; $54.70 \%$; $45.01 \%$ and $54.40 \%$ respectively for groups $1,2,3,4$. Compared to the other groups, the mean egg production of group 3 (32\%CP) hens was significantly lower $(\mathrm{P}<0.05)$. Apart from group 2 where the weekly egg production appears relatively constant after week 4, production in all other groups showed a decreasing pattern after week 4 (Table 3).

Table 4 shows significant differences between treatment durations (week) and between CP but not between drug application in the overall study. Interactions between duration of treatment and CP as well as the interaction between drug application, duration of application and CP together significantly effected performance. There were no significant interactions between the effects of drug application and treatment duration (both on daily and weekly basis) on performance.

Table 1: Time (days) of Post Moult-Menarche and Return to Pre-moult Status

\begin{tabular}{cccc}
\hline Group & Treatment & $\begin{array}{c}\text { Menarche Time } \\
\text { (Day) }\end{array}$ & $\begin{array}{c}\text { Return To Pre- } \\
\text { Moult Status }\end{array}$ \\
1 & $16 \%$ & Day 1 & Day 9 \\
2. & $16 \%+$ & Day 4 & Day 8 \\
3. & $32 \%$ & Day 3 & Day 8 \\
4. & $32 \%+$ & Day 3 & Day 8 \\
\hline
\end{tabular}


Crude protein level manipulation and Moulted, Aged Hens

Table 2: Post Moult (PM) Hen-day Production Peak (\%)

\begin{tabular}{llll}
\hline Group & Treatment & $\begin{array}{l}\text { Hen Day Peak } \\
(\%)\end{array}$ & Time (Day) \\
\hline 1 & $16 \%$ & 87.5 & Day 34 \\
2. & $16 \%+$ & 91.7 & Day 49 \\
3. & $32 \%$ & 68.0 & Day 27 \\
4. & $32 \%+$ & 83.3 & Day 28 \\
\hline
\end{tabular}

Table 3: Peak Weekly Production Performance Recovery of PM, Aged Hens as affected by CP and FS Treatment.

\begin{tabular}{ccccc}
\hline \multicolumn{5}{c}{ GROUP } \\
\hline Week & 1 & 2 & 3 & 4 \\
& & & & \\
\hline Week & $16 \%$ & $16 \%^{+}$ & $32 \%$ & $32 \%^{+}$ \\
1 & 9.53 & 5.94 & 13.4 & 13.70 \\
2 & 47.63 & 45.83 & 39.43 & 50.59 \\
3 & 63.69 & 57.16 & 54.29 & 57.16 \\
4 & $69.66^{*}$ & 61.91 & $56.40^{*}$ & $63.69^{*}$ \\
5 & 66.07 & 64.87 & 54.29 & 60.11 \\
6 & 64.29 & 60.69 & 49.71 & 58.93 \\
7 & 61.30 & $67.26^{*}$ & 47.43 & 51.19 \\
8 & 55.96 & 60.13 & 47.43 & 47.03 \\
9 & 54.77 & 60.73 & 45.14 & 54.79 \\
10 & 51.79 & 62.44 & 42.86 & 44.64 \\
Mean & $59.48^{\text {a }}$ & $54.70^{\text {a }}$ & $45.01^{\mathrm{b}}$ & $54.40^{\mathrm{a}}$ \\
SE & 7.47 & 7.12 & 5.62 & 6.34 \\
\hline
\end{tabular}

Means in the row followed by the same superscript are not significantly different ( $p>0.05)$.

* $\quad$ Peak attainment in Weekly Production Performance.

PM, Post-moult; CP: crude protein; FS: Follicular stimulation.

Table 4: Mean Squares for the effects of CP, FS. Treatment duration (week) and their interactions on the post-moult recovery performance of aged hens

\begin{tabular}{lll}
\hline Source of Variation & Df & Mean Square \\
\hline CP & 1 & $3563.93^{*}$ \\
Drug & 1 & $455.05^{\mathrm{ns}}$ \\
Week & 9 & $6392.85^{*}$ \\
Day & 6 & $147.57^{\mathrm{ns}}$ \\
CP + Day & 6 & $380.43^{\mathrm{ns}}$ \\
CP + Week & 9 & $3334.50^{*}$ \\
CP + Drug + Day & 27 & $240.63^{\mathrm{ns}}$ \\
CP + Drug + Week & 39 & $1687.46^{*}$ \\
Drug + Week & 9 & $36.58^{\mathrm{ns}}$ \\
Drug + CP & 1 & $376.0^{\mathrm{ns}}$ \\
* $\quad$ Significant $(p<0.05)$ \\
ns $\quad=\quad$ Not significant $(p>0.05)$ \\
CP $\quad=\quad$ Crude Protein
\end{tabular}




\section{Discussion}

Post - moult menarche occurred between days 1 and 4 in all the groups in this study. The achievement of the peak of $87.5 \%$ on the $34^{\text {th }}$ day (6 weeks) post moult by the hens on control diet (Group $1-16 \%$ without follicle stimulation), indicates a better performance over the report of Odunsi et al, (2002) on Black Harco layers subjected to moulting at 82 weeks of age. Post moult laying performance reached above $60 \%$ only after six weeks of feeding. It is also superior to the Lohman layers subjected to moulting at an older age of 128 weeks by Oguike and Ezeoke, (2003). Post moult egg production reached $50 \%$ at 6 weeks and peaked at $63 \%$ by the $8^{\text {th }}$ week. PM menarche in these birds was noticed on day 6 with a comparable layer diet. The improved performance in the current study can be attributed to the older age of the hens, when compared to the Black Harco, and to their younger age when compared to the Lohman layers. This observation could be a pointer to an age at which post moult recovery in aged hens could be optimum. Both the breed and management factors could be at play when the two other breeds are taken together in comparison with the result of this study. A further explanation is that during the feed restriction period, the body draws on its tissue reserves for sustenance. The birds in this study were thus able to regenerate their tissues apparently faster than the younger Black Harco hens (with higher metabolic rate), probably because less wasting of their body tissues took place during the period of feed restrictions, and the older Lohman hens (with probably lower efficiency in feed utilization). It was therefore easier for them to resume another production phase as soon as normal feeding commenced. This age of hens could therefore be seen to have shown a greater sensitivity to the moulting treatment. The attainment of premoult capacity within the first 8 days PM and the relatively quick attainment of various peak production performances are obvious indications that production loss, on account of moulting, could be easily recouped at such an age in adequately managed laying hens.

The better performance of group 1 hens compared with group 3 (with doubled CP level in their diet) nullifies the need for higher $\mathrm{CP}$ inclusion in the diets of aged laying hens. This is because such indices as PM menarche and return to pre-moult production capacity (Table 1); peak production level and its day of attainment (Table 2) all suggest that the animals that received 16\% CP diet showed better performance compared with 32\% CP diet (Table 3).
This observation is buttressed further by the fact that the group 3, that received 32\% CP diet without FS peaked only at 68\% PM hen-day production. This is significantly lower than all the other groups. Group 4, that received $32 \% \mathrm{CP}+$ peaked at $83.3 \%$, a value, numerically lower than the group 1 fed $16 \%$ $\mathrm{CP}$ and group 2 fed 16\% CP + though the differences were not significant. (Table 2)

Clomifene citrate treatment enhanced the attainment of higher PM hen-day peak production compared with their untreated counterparts in both groups 2 and 4 (Table 2). It enhanced weekly production performance in group 4 birds over their untreated counterparts and extended the period of higher production levels in group 2 hens, resulting in higher peak weekly production performance of this group over groups 3 and 4 (Table 3 ). The mean weekly egg production performance during the experimental period suggests group 1 as having the best performance of all the groups compared to groups 2 and 4, while the production performance of group 3 hens was significantly lower than all the other groups (Table 3). These observations might not support the application of follicle stimulation (FS) and the inclusion of higher crude protein level (CP) in the diet of post - moulted (PM) aged laying hens.

The results from this study therefore indicate that $16 \% \mathrm{CP}$ and follicular stimulation significantly enhanced PM hen day production. Dietary manipulation does not impact PM menarche (Table 1). Thus, higher protein level did not per se enhance peak production, return to pre-moult production status, and PM menarche both in capacity and in timing. The significantly higher overall weekly performance of hens fed with 16\% CP without FS (Group 1) than those fed 32\% CP without FS (Group 3) and its non-significant ( $>>0.05)$ higher value over the 16\% CP + (Group 2) and $32 \% \mathrm{CP}+$ (Group 4) rations make FS and higher protein inclusion in the diets of PM, aged, laying hens necessary, probably only for specific, targeted purposes such as when there is the need to overstrech old layers prior to an impending culling programme.

\section{Acknowledgement:}

We acknowledge the technical support of Messrs J. A. Bankole, O. A. Oyebode and T. A. Bakare of the LAUTECH Commercial Farm.

\section{References}

Bar, A., Razaphkovsky, V., Wax, E., and Malka, Y (2001). Effect of age at 
moulting on postmoulting performance. Poultry Science. 80:7, 874-878.

Decuypere, E. and Verheyen, H. (1986). Physiological basis of induced moulting and tissue regeneration in fowls. World's Poult. Sci. Journal 42: 56-68.

Dubinskii, P. I., Danilova, A. K. and Shpits, I.S. (1973). The effects of artificial moulting on the physiology, egg production and egg quality of fowls. Sbornik Nauchnykh Trudov Moskovskaya Veterinarnaya Akademiya. No. 64, 139143.

Monteiro, N.M. da C., Andrade, A. N. de., Britto, D.P. P. de S., Guimaraes, J. F., Sinzato, D., and Costa, F. A. (1971). A comparison between forced and natural moult in White Leghorn hens caged at two different densities. Pesquisa Agropecuaria Brasileira, Veterinaria. 6: (4) 33-36.

Odunsi, A. A., Farinu, G. O. and Togun, V. A. (2002). Diet manipulation and postmoulting responses in caged commercial laying hens. Nig. J. Anim. Prod. 29 (1): 11-15.

Oguike, M. A. and Ezeoke, I. O. (2003). Recycling of old layers using forced moulting. In Taiwo A. A., Raji, A. M., Ogbonna J.U and Adebowale, E. A. (eds) Nigeiran Livestock: A Goldmine For Economic Growth and Food Security. Proceedings of the $28^{\text {th }}$ Annual Conference. Nigerian Society for Animal Production, held at the Institute of Agricultural Research and Training, Obafemi Awolowo University, Ibadan, Nigerian. pp. $92-95$.

Swanson, M. H. and Bell, D. D. (1970). Field tests of forced moulting practices and performance in commercial egg production flocks. XIV World's Poultry Congress. Scientific Communications. Housing and Management. Pathology, Production and Economy. Industrialization and Commerce. Madrid Ministerio de Agricultural, Spain 87-97.

Zvykas, E. B. (1977). Studies on the production of hens in relation to variation in body weight during forced moulting. Sbornik Rabot. Pribaltii Skaya Zonal'naya Opytnaya Stantsiya po Ptitsevodstvu. No.5, 38-48.

Received: September 24, 2004

Accepted: October 6, 2004 